\title{
Modern Erosion Rates and Loss of Coastal Features and Sites, Beaufort Sea Coastline, Alaska
}

\author{
BENJAMIN M. JONES,,${ }^{1,2}$ KENNETH M. HINKEL,${ }^{3}$ CHRISTOPHER D. ARP ${ }^{1}$ and WENDY R. EISNER ${ }^{3}$
}

(Received 1 October 2007; accepted in revised form 4 January 2008)

\begin{abstract}
This study presents modern erosion rate measurements based upon vertical aerial photography captured in 1955, 1979, and 2002 for a $100 \mathrm{~km}$ segment of the Beaufort Sea coastline. Annual erosion rates from 1955 to 2002 averaged $5.6 \mathrm{~m} \mathrm{a}^{-1}$. However, mean erosion rates increased from $5.0 \mathrm{~m} \mathrm{a}^{-1}$ in $1955-79$ to $6.2 \mathrm{~m} \mathrm{a}^{-1}$ in $1979-2002$. Furthermore, from the first period to the second, erosion rates increased at 60\% (598) of the 992 sites analyzed, decreased at 31\% (307), and changed less than $\pm 30 \mathrm{~cm}$ at $9 \%$ (87). Historical observations and quantitative studies over the past 175 years allowed us to place our erosion rate measurements into a longer-term context. Several of the coastal features along this stretch of coastline received Western place names during the Dease and Simpson expedition in 1837, and the majority of those features had been lost by the early 1900s as a result of coastline erosion, suggesting that erosion has been active over at least the historical record. Incorporation of historical and modern observations also allowed us to detect the loss of both cultural and historical sites and modern infrastructure. U.S. Geological Survey topographic maps reveal a number of known cultural and historical sites, as well as sites with modern infrastructure constructed as recently as the 1950s, that had disappeared by the early 2000s as a result of coastal erosion. We were also able to identify sites that are currently being threatened by an encroaching coastline. Our modern erosion rate measurements can potentially be used to predict when a historical site or modern infrastructure will be affected if such erosion rates persist.
\end{abstract}

Key words: Alaska, Arctic, Beaufort Sea coastline, coastal erosion, shoreline analysis

RÉSUMÉ. Cette étude présente les mesures de taux d'érosion contemporains établies en fonction de photographies aériennes verticales prises en 1955, en 1979 et en 2002 sur un segment de $100 \mathrm{~km}$ du littoral de la mer de Beaufort. Entre 1955 et 2002, les taux d'érosion annuels ont atteint 5,6 $\mathrm{m} \mathrm{a}^{-1}$ en moyenne. Cependant, les taux d'érosion moyens se sont accrus pour passer de $5,0 \mathrm{~m} \mathrm{a}^{-1}$ pendant les années 1955 - 1979 à $6,2 \mathrm{~m} \mathrm{a}^{-1}$ dans les années 1979-2002. Par ailleurs, de la première période à la deuxième période, les taux d'érosion ont augmenté à $60 \%$ (598) des 992 sites analysés, ont diminué dans le cas de $31 \%$ (307) des sites, et changé de moins de $\pm 30 \mathrm{~cm}$ à $9 \%$ (87) des sites. Les observations historiques et les études quantitatives recueillies au cours des 175 dernières années nous ont permis de placer nos mesures des taux d'érosion dans un contexte à plus long terme. Plusieurs des caractéristiques côtières le long de cette étendue du littoral ont reçu des noms d'endroits typiques de l'Ouest dans le cadre de l'expédition de Dease et Simpson en 1837, et la majorité de ces caractéristiques avaient disparu vers le début des années 1900 en raison de l'érosion côtière. Cela laisse donc entendre que l'érosion s'est à tout le moins manifestée pendant la période visée par les données historiques. Grâce à l'utilisation d'observations historiques et d'observations contemporaines, nous avons pu déceler la perte de sites culturels et historiques de même que d'infrastructures modernes. Les cartes topographiques de l'U.S. Geological Survey révèlent un certain nombre de sites culturels et historiques connus, ainsi que des sites dotés d'infrastructures modernes datant des années 1950, sites et infrastructures qui avaient disparu vers le début des années 2000 en raison de l'érosion côtière. Nous avons également été en mesure de cerner des sites qui sont présentement menacés par un littoral qui empiète sur le terrain. Nos mesures des taux d'érosion contemporains pourraient éventuellement servir à déterminer à quel moment un site historique ou une infrastructure moderne sera touché advenant que des taux d'érosion similaires persistent.

Mots clés : Alaska, Arctique, littoral de la mer de Beaufort, érosion côtière, analyse de la rive

Traduit pour la revue Arctic par Nicole Giguère.

\section{INTRODUCTION}

Rates of shoreline erosion along Arctic coastlines are among the highest in the world (Reimnitz et al., 1985; Bird, 2000). Long-term rates of erosion along the Alaska Beaufort Sea coast have averaged $2.5 \mathrm{~m} \mathrm{a}^{-1}$, with higher rates occurring along the western stretches ( 3.0 to $5.4 \mathrm{~m} \mathrm{a}^{-1}$ ) and lower rates occurring along the eastern stretches (1.0 to $1.4 \mathrm{~m} \mathrm{a}^{-1}$ ) (Lewellen, 1970; Reimnitz et al., 1985; Barnes et al., 1992; Brown et al., 2003; Jorgenson et al., 2003; Manley, 2004). By comparison, recent long-term rates of erosion along the Canadian Beaufort Sea coast

\footnotetext{
${ }^{1}$ U.S. Geological Survey, Alaska Science Center, Anchorage, Alaska 99508, USA

${ }^{2}$ Corresponding author: bjones@usgs.gov

${ }^{3}$ Department of Geography, University of Cincinnati, Cincinnati, Ohio 45221-0131, USA

(C) The Arctic Institute of North America
} 


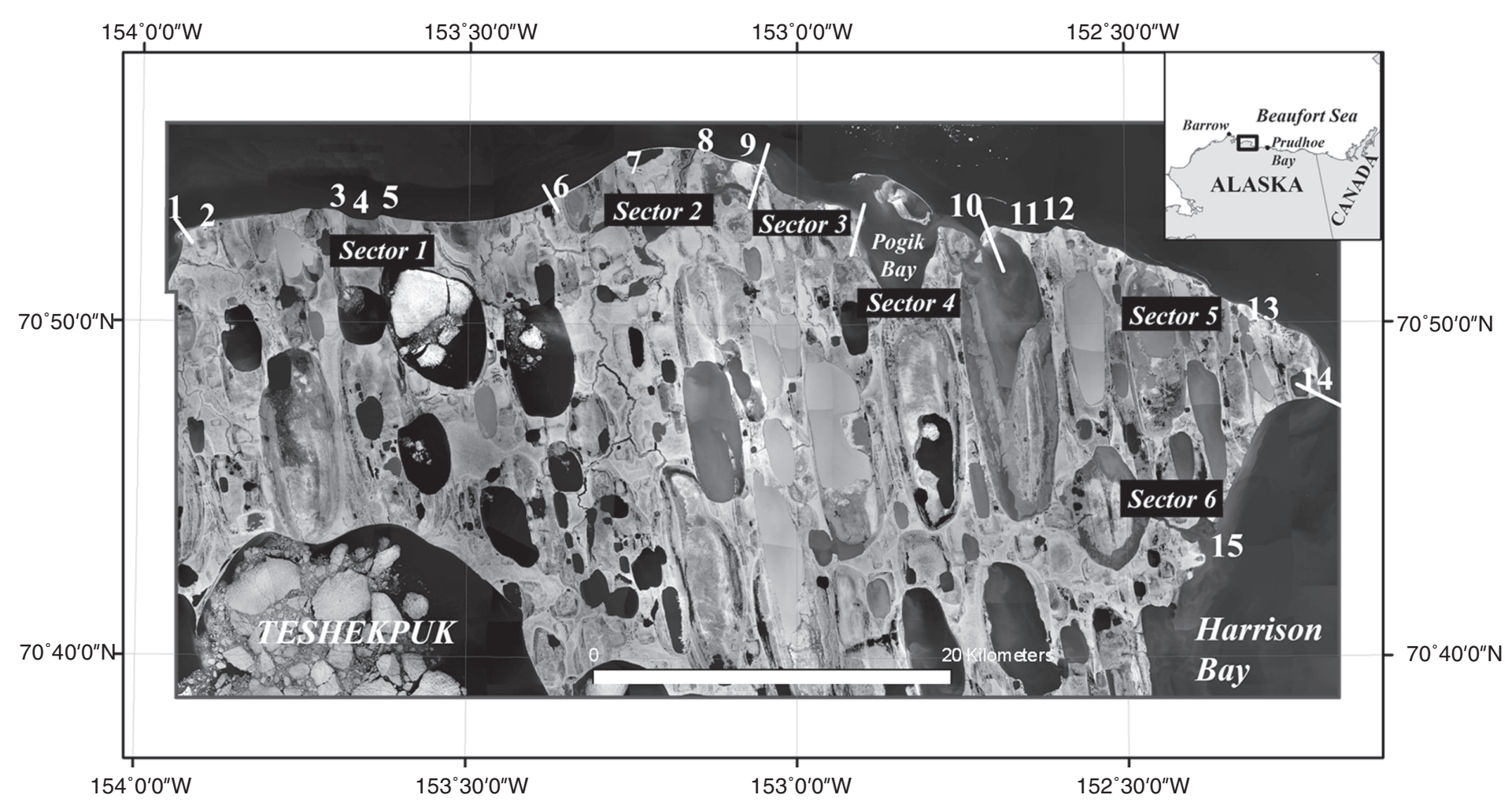

FIG. 1. Photomosaic showing the location of the study area along the Beaufort Sea coast (inset). The numbers represent features and sites discussed in the text and listed in Table 1; these include coastal features, known cultural/historical sites, and modern infrastructure. The sectors were defined by Reimnitz et al. (1985).

have averaged 1.0 to $2.0 \mathrm{~m} \mathrm{a}^{-1}$ (Mackay, 1986; Harper, 1990; Solomon, 2005).

Located along the west-central portion of the Alaska Beaufort Sea coast is the Teshekpuk Lake Special Area (TLSA), which includes nearly $140 \mathrm{~km}$ of coastline within the National Petroleum Reserve-Alaska (NPRA). This area has recently received much attention since it is believed to be rich in petroleum reserves (Bird and Houseknecht, 2002), but it is also important because of its rich subsistence hunting grounds for Inupiat Eskimos, the abundance of migratory, molting waterfowl (Bollinger and Derksen, 1996), and the presence of the Teshekpuk caribou herd (Person et al., 2007). Examination of historical accounts of this stretch of coastline (Dease and Simpson [Simpson, 1843]; Maguire, 1854; Leffingwell, 1919), the Dictionary of Alaska Place Names (Orth, 1967), and the U.S. Geological Survey (USGS) topographic maps dating to 1955 reveals a number of coastal features with Western place names, cultural and historical sites, and modern sites located along the TLSA coast that could have potentially disappeared as a result of coastal erosion. The goal of this study is to quantify shoreline change and coastal erosion rates on the basis of aerial photographs taken in 1955, 1979, and 2002 in order to determine the sites that have been lost over the duration of the photographic record, identify existing sites that are currently being threatened by erosion, and link modern erosion rates to past observations.

\section{STUDY AREA AND BACKGROUND}

The Arctic Coastal Plain (ACP) of northern Alaska is an emergent part of the continental shelf of northern Alaska (Carson and Hussey, 1962). Today, the Alaskan Beaufort Sea coastline extends $1957 \mathrm{~km}$ along the ACP, from Point Barrow to Demarcation Point at the U.S.-Canadian border (Jorgenson and Brown, 2005). Since the Late Cenozoic, seven to eight marine transgressions have been identified across the ACP as is evidenced by remnant beaches, wavecut scarps, and marine deposits (Hopkins, 1967, 1973; Brigham-Grette and Carter, 1992; Brigham-Grette and Hopkins, 1995; Brigham-Grette, 2001).

The TLSA is located about midway between Barrow and Prudhoe Bay (Fig. 1). The modern TLSA coastline is bounded by Harrison Bay to the east and Smith Bay to the west. At the northern and southern margins of Teshekpuk Lake lie the remnants of former shorelines of two transgressions that have occurred during the past 125 kya. The older Pelukian transgression is associated with the Sangamon interglacial ( 123 kya, isotope substage 5e), when sea level was $10-13 \mathrm{~m}$ higher than present. Superimposed on this surface is the interstadial Simpsonian transgression around 78-58 kya (isotope substage $5 \mathrm{a} / 4$ ), when sea level was $7-10 \mathrm{~m}$ higher than present. During this transgression, glaciomarine silts and ice-rafted erratics were deposited as the Flaxman Member of the Gubic formation (Carter et al., 1988; Dinter et al., 1990; Brigham-Grette and Hopkins, 1995). Sea level has probably not transgressed more than $2 \mathrm{~m}$ across the ACP 
TABLE 1. List of sites discussed in the text, showing name, source, feature type (coastal feature, cultural/historical site, modern infrastructure), whether it has eroded, and during which time period. The site numbers refer to the locations shown on Figure 1.

\begin{tabular}{|c|c|c|c|c|c|}
\hline Number & Site & Sources & Type & Eroded? & Time Period \\
\hline 1 & Point Drew & Dease and Simpson, Leffingwell, USGS & Place Name & No & 1837 -present \\
\hline 2 & Point Drew Test Well & USGS & Infrastructure & No & 1978 -present \\
\hline 3 & Point McPherson & Dease and Simpson, Leffingwell & Place Name & Yes & $1837-1919$ \\
\hline 4 & Deer Pound & Dease and Simpson & Cultural/Historical & Yes & $1837-1919$ \\
\hline 5 & Point McLeod & Dease and Simpson, Leffingwell & Place Name & Yes & $1837-1919$ \\
\hline 6 & Kolovik & USGS & Cultural/Historical & No & pre-1951-present \\
\hline 7 & Lonely DEW Station & USGS & Infrastructure & No & 1953 -present \\
\hline 8 & J.W. Dalton Test Well & USGS & Infrastructure & Yes & $1978-2004$ \\
\hline 9 & Kokruagarok & USGS & Cultural/Historical & Yes & pre-1951-2002 \\
\hline 10 & Point Ellice & Dease and Simpson & Place Name & Yes & $1837-1919$ \\
\hline 11 & Cameron Point & Dease and Simpson, USGS & Place Name & Yes & $1837-2002$ \\
\hline 12 & Esook Trading Post & USGS, Kovacs & Cultural/Historical & Yes & pre-1949-2002 \\
\hline 13 & Foran Test Well & USGS & Infrastructure & No & $1977-$ present \\
\hline 14 & Cape Halkett & Dease and Simpson, Leffingwell, Reimnitz, USGS & Place Name & Yes & $1837-1945$ \\
\hline 15 & Point Comfort & Dease and Simpson, Leffingwell & Place Name & Yes & $1837-1919$ \\
\hline
\end{tabular}

since that time (Péwé, 1975). Analysis of sea level history across the ACP has shown that the strandlines have roughly the same elevation across the landscape, indicating that the region has been tectonically stable at least over the last $125 \mathrm{ka}$ (Dinter et al., 1990).

The land surface expression in the TLSA is of low elevation and relief. It is typical of the outer portion of the Western ACP, in that the area is covered by numerous oriented thaw lakes, drained thaw-lake basins, localized erosional remnants, strand lines, and paleo beach ridges and barrier islands (Hinkel et al., 2003, 2005; Eisner et al., 2005). The surficial geology is characterized by organicrich, glacio-marine silty sediments, deposited during the Simpsonian transgression, that have been cemented by permafrost. The permafrost is continuous and relatively high in ice content, with more than $20 \%$ ice by volume in the upper 10-20 $\mathrm{m}$ and upwards of $70 \%$ in the upper $1-2 \mathrm{~m}$, and it extends to depths of 300-600 m (Sellmann et al., 1975; Brown et al., 1997).

A number of coastal features with Western place names and cultural and historical sites are shown on the 1:63000 scale USGS topographic maps from 1955, listed in the Dictionary of Alaska Place Names (Orth, 1967), and described by Leffingwell (1919) and Dease and Simpson (Simpson, 1843). In fact, several of the coastal features were named during the voyage of Dease and Simpson in 1837 (Simpson, 1843), whereas the previously identified cultural and historical sites, of uncertain age, were first described by Westerners around 1900. More recently, a Distance Early Warning (DEW) station was constructed at Lonely in 1955, and three exploratory petroleum wells were drilled in the northern TLSA in the late 1970s (Fig. 1, Table 1).

\section{HISTORICAL OBSERVATIONS AND QUANTITATIVE STUDIES}

A number of observations and historical maps exist for the TLSA coastline that date to the early days of exploration in search of the Northwest Passage. The historic voyage of Dease and Simpson in the 19th century produced the first map of the coastline for this region, as well as providing place names for many of the coastal geographic features (e.g., Harrison Bay, Cape Halkett, and Point Drew) (Figs. 1 and 2, Table 1). Commander Maguire's voyage during the period $1852-54$, in search of Sir John Franklin and his crew, provided another historical map of the coastline. At the beginning of the 20th century, Ernest De K. Leffingwell (1919) published his observations on the region. Driven by the need for a more detailed analysis of the Beaufort Sea coastline, Leffingwell (1919) revisited many of the sites described by earlier explorers and was able to locate and archive information about many of the previously named geographical features.

Detailed field studies of the coastline were later conducted by Reimnitz et al. (1985) of the USGS and Kovacs (1983, 1984) with the U.S. Army Cold Regions Research and Engineering Laboratory (CRREL). Reimnitz et al. (1985) divided the TLSA coastline into six sectors and described shoreline erosion processes and calculated rates of erosion for each, using nautical charts created in 1949 and 1980. Kovacs examined coastline morphometry and sea ice pile-up effects, and documented erosion rates near Esook Trading Post. More recently, Mars and Houseknecht (2007) reported results from a land loss-land gain study of the northern TLSA based on cartographic data and satellite imagery from the period 1955 to 2005. Their analysis suggested that the rate of loss of coastal land area doubled over the 50 years from 1955 to 2005 as a result of increased erosion.

Although these observations and studies were performed for different reasons and employed different techniques, they provide a valuable resource for examining coastline change over the past 175 years. Combining the information from these historical observations and past quantitative studies provides insight as to the origin of the names of coastal features, the location of cultural and historical sites, and past erosion rates. The photographic analysis of shoreline erosion employed in this study, in combination with these data, allows identification of sites lost or currently threatened by coastal erosion. 


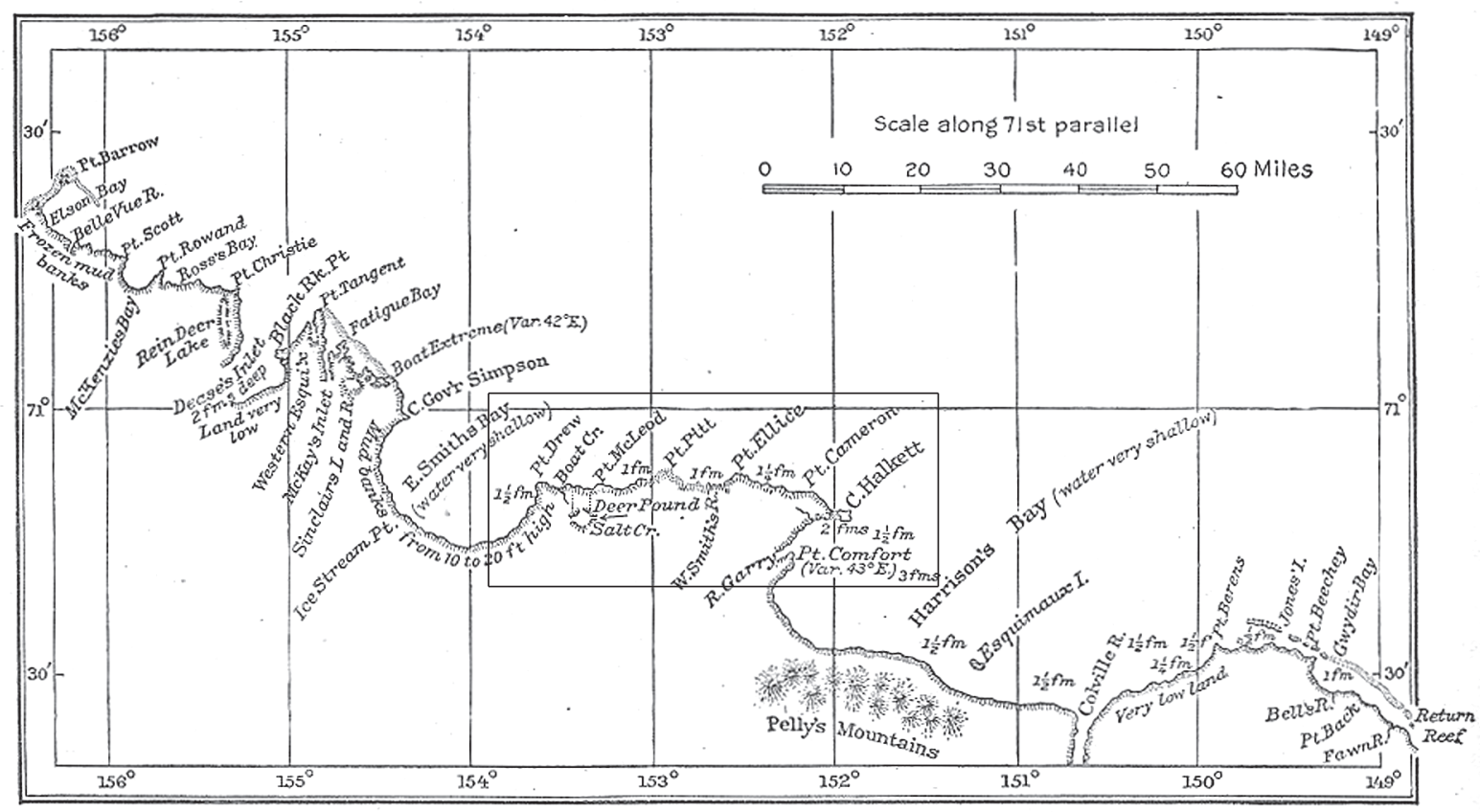

FIG. 2. A reproduction of Dease and Simpson map of the north coast of Alaska, 1837 (Leffingwell, 1919). The rectangle outlines the coastline examined in the present study.

\section{METHODS}

\section{Imagery}

In order to accurately quantify erosion rates for the TLSA coastline, we used high spatial resolution $(2.5 \mathrm{~m})$ aerial photography from 1955,1979 , and 2002 . The baseline aerial photography used in this study was acquired on 18 July 2002 by Aero-Metric of Anchorage, Alaska, at a scale of 1:40 000 on Kodak SO-734 or equivalent colorinfrared (CIR) film. All images were scanned at 56 micron on a Ziess SCAI scanner running Photoscan $2001^{\circledR}$ software, resulting in a ground-based resolution of $2.5 \mathrm{~m}$. Tiepoint generation and point measurement were completed using ImageStation Automatic Triangulation ${ }^{\circledR}$. The aerotriangulation was computed on the NAD83 (2002.0) horizontal datum using the Universal Transverse Mercator (UTM) coordinate system, zone 5, and an interferometric synthetic aperture radar (IFSAR)-derived digital surface model (DSM) was used for the ortho-correction. In order to cover the entire study area shown in Figure 1, 17 frames of the photography were mosaicked.

The 2002 photography provides a recent time stamp and serves as the base map for reference and comparison to the other photo data sets. The 1955 aerial photography consisted of black-and-white imagery collected at a scale of 1:55000 and acquired in August. The 1979 imagery consisted of color infrared photography at a scale of 1:63000 and acquired in July. Each photo data set required 12 frames to cover the study area.

Selection of ground control points (GCPs) was based on knowledge of the area and used distinct ground features, typically ice-wedge polygon intersections apparent in each time period and small islands located in areas rich in lowcenter polygons that showed little variation across the three image dates. GCPs were concentrated within $1.5 \mathrm{~km}$ of the 2002 shoreline; therefore, a first-order polynomial was used for rectification to prevent major distortion caused by this configuration of control points. Thus, for the 1955 photography, on average 15 GCPs were selected for each of the 12 frames. The mean RMS error associated with the points was $2.6 \mathrm{~m}$, with a minimum of $1.6 \mathrm{~m}$ and a maximum of $3.6 \mathrm{~m}$ per frame. For the 1979 photography, the average number of GCPs selected across the 12 frames was about 14 per frame; the mean RMS error was $3.0 \mathrm{~m}$, with a minimum of $1.5 \mathrm{~m}$ and a maximum of $4.4 \mathrm{~m}$.

Lunar tides associated with this area are roughly $40 \mathrm{~cm}$ (Alaska Ocean Observing System, 2008). However, winddriven tides can account for water-level differences of nearly $3 \mathrm{~m}$; westerly winds tend to elevate water levels, whereas easterly wind events tend to lower water levels (Reimnitz and Maurer, 1979). We analyzed weather conditions at Barrow, Alaska, 72 hours prior to each image acquisition to ensure that a major wind event had not occurred. Fairly calm conditions existed during both the 1979 and 2002 image acquisitions. In 1955, however, a $7.2 \mathrm{~m} / \mathrm{s}$ easterly wind event lasting approximately 12 hours occurred on the day before acquisition of the imagery; thus, water levels might have been lowered slightly. The only areas likely to be affected by such minor fluctuations in water level would be areas buffered by a beach or a spit; however, the majority of the bluffs are exposed and directly abut the waterline (Reimnitz et al., 1985). Therefore, neither lunar nor wind-driven tides likely affect erosion rate measurements. 


\section{Shoreline Classification}

It was determined that a semi-automated technique of delineating the coastline would provide optimal results and allow for replication, as compared to methods requiring manual delineation of the shoreline. Each image mosaic was imported in eCognition ${ }^{\circledR}$; the 1955 imagery consisted of the single black-and-white band, while the red band was used for the 1979 and 2002 imagery.

The first step involved segmenting the image using a scale parameter of 50, a shape factor of 0.1 , and a smoothness and compactness of 0.5 in normal segmentation mode. Next, a secondary segmentation with the same scale, shape, and smoothness/compactness parameters was run; however, the segmentation mode was changed to spectral differencing. This effectively grouped a number of the smaller image objects into larger objects on the basis of the spectral characteristics of neighboring image objects. Image objects were then grouped, using the image object fusion function, to depict the boundary between the ocean water and the land accurately. A few areas were problematic because of bright reflectance caused by the presence of ice near the beach deposits, and these minor areas were manually corrected.

\section{Erosion Rates}

Rates of erosion were determined for the three time periods with the Digital Shoreline Analysis System (DSAS v. 3.2) extension for ESRI's ArcMAP ${ }^{\circledR}$ created by the USGS in Woods Hole, Massachusetts (Thieler et al., 2005). DSAS, which was designed to aid in historical shoreline change analysis, enables users to calculate shoreline erosion rates from a time series of multiple shoreline positions. DSAS generates orthogonal transects at user-defined intervals along a coastline and calculates the rate of change between two points on the basis of the elapsed time and the linear distance. The required inputs for DSAS consist of a sequential time series of vector shoreline positions and a usercreated reference baseline to serve as the starting point for generating transects. The baseline was created manually, and transects were created using the simple cast function with a spacing of $100 \mathrm{~m}$. This method effectively calculated erosion rates for 992 points along this $\sim 100 \mathrm{~km}$ stretch of coastline for 1955-79, 1979-2002, and 1955-2002.

\section{Error Analysis}

Since errors are inherent in this analysis, it is necessary to quantify the potential error of shoreline positions used for the analysis of erosion rates. The total error is the sum of the error resulting from georeferencing the photography and from classifying the shoreline. The RMS errors associated with image registration averaged $2.6 \mathrm{~m}$ for the 1955 photography and $3.0 \mathrm{~m}$ for the 1979 photography. To assess the accuracy of the semi-automated shoreline delineation, $10 \%$ of the 992 transects were randomly
TABLE 2. Erosion rates for the time periods 1955-2002, $1955-$ 79 , and 1979-2002, reported in $\mathrm{m} \mathrm{a}^{-1}$. A positive sign signifies progradation.

\begin{tabular}{lrcc}
\hline \hline $\mathrm{N}=992$ & $1955-2002$ & $1955-79$ & $1979-2002$ \\
\hline Mean & 5.6 & 5.0 & 6.2 \\
Median & 3.8 & 3.4 & 4.3 \\
Standard Deviation & 5.7 & 6.2 & 6.5 \\
Minimum & 25.9 & 49.6 & 25.3 \\
Maximum & +11.3 & +39.0 & +33.2 \\
\hline \hline
\end{tabular}

selected. The classification of the coastline for each of the three photo acquisition periods was compared to the photo, and the distance from the classified coastline to the observed coastline was measured. Combining the results from the two sources of error suggests that the total error associated with using these methods to monitor shoreline erosion rates was $0.34 \mathrm{~m} \mathrm{a}^{-1}$ for $1955-79,0.25 \mathrm{~m} \mathrm{a}^{-1}$ for 1979-2002, and $0.11 \mathrm{~m} \mathrm{a}^{-1}$ for $1955-2002$.

\section{RESULTS AND DISCUSSION}

\section{Modern Erosion Rates}

From 1955 to 2002, erosion rates averaged $5.6 \mathrm{~m} \mathrm{a}^{-1}$ along this $\sim 100 \mathrm{~km}$ stretch of coastline. However, the median value was somewhat lower $\left(3.8 \mathrm{~m} \mathrm{a}^{-1}\right)$, indicating a non-normal distribution with lower erosion rates predominating (Table 2). There was considerable range in erosion rates along the coastline (Fig. 3a), with some sites evidencing progradation $\left(11.3 \mathrm{~m} \mathrm{a}^{-1}\right)$ while others experienced extreme erosion $\left(25.9 \mathrm{~m} \mathrm{a}^{-1}\right)$. Sites of progradation or deposition tended to be located along spits and promontories of land where the coastline made a sudden change in orientation. Sites experiencing extreme erosion tended to occur along sections of exposed coast that faced to the north or northeast.

The data can also be analyzed for periods of nearly equal duration by incorporating the shoreline position delineated from the 1979 photography. The mean erosion rate during the 24-year period $1955-79$ is $5.0 \mathrm{~m} \mathrm{a}^{-1}$, while the 23-year period 1979-2002 averaged $6.2 \mathrm{~m} \mathrm{a}^{-1}$; application of the Mann-Whitney U (Wilcoxon rank sum) test indicates that the erosion rates are statistically different at the 0.05 significance level. The earlier period is characterized by greater extremes, with a maximum measured erosion rate $\left(49.6 \mathrm{~m} \mathrm{a}^{-1}\right)$ twice the magnitude of that of the latter period $\left(25.3 \mathrm{~m} \mathrm{a}^{-1}\right)$; however the mean and median erosion rates were both greater in the latter time period. The maximum erosion rate recorded in the earlier time period is somewhat anomalous, as it appears that erosion occurred through a low-lying deltaic deposit at the northern end of a recently tapped thaw-lake. Once this material was removed, shoreline erosion rates decreased. Furthermore, of the total 992 sites analyzed in the two time periods, $60 \%$ (598) experienced increased erosion rates in 

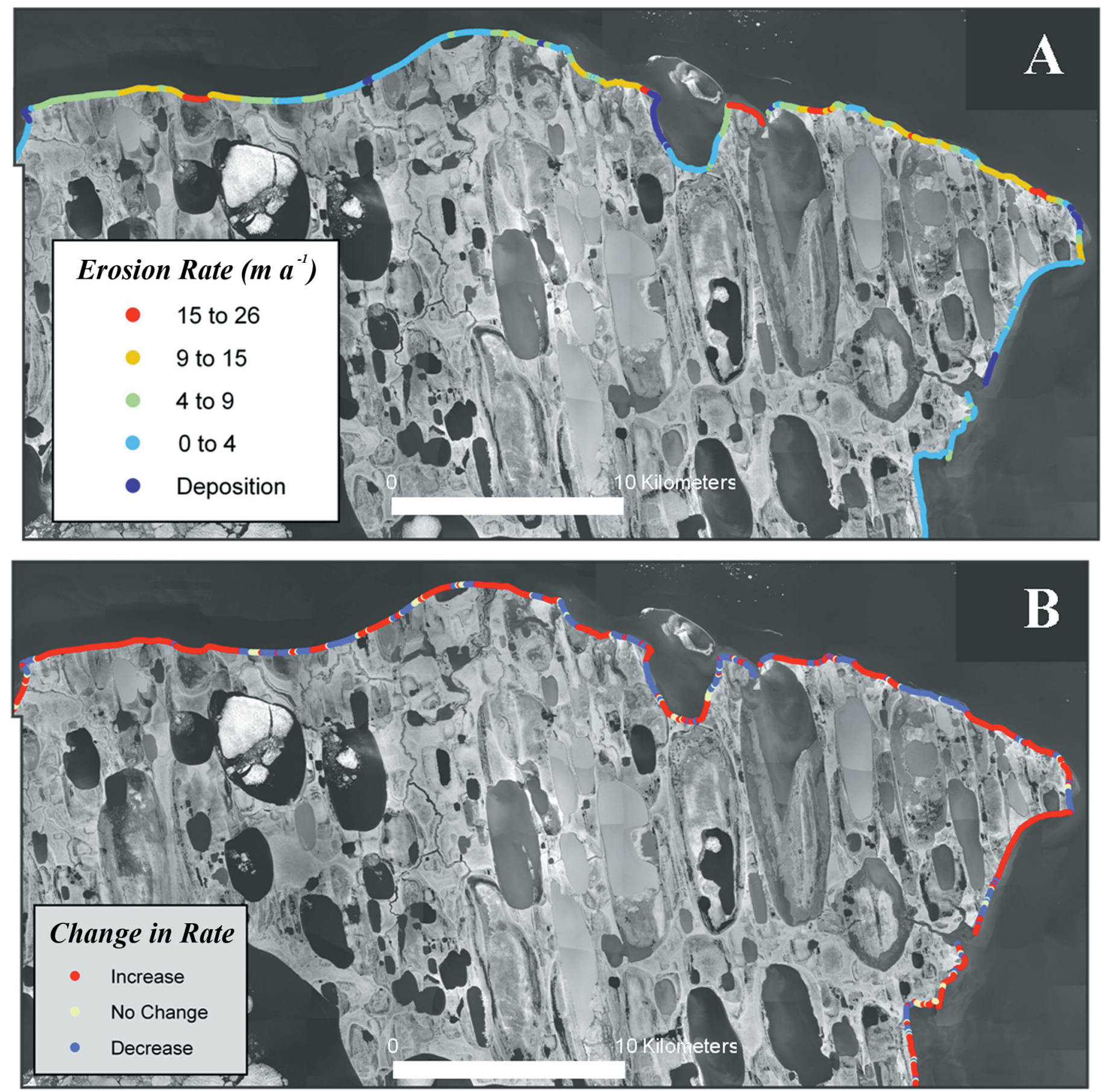

FIG. 3. (A) Photomosaic (2002) with overlay of mean annual erosion rate for the study area (1955-2002), measured at 100 m increments. (B) Photomosaic (2002) with overlay showing the change in erosion rate from 1955-79 to 1979-2002. Red indicates an increase in erosion rate, blue signifies a decrease, and light yellow indicates little change (less than $\pm 30 \mathrm{~cm}$ ).

the more recent time period, $31 \%$ (307) had decreased erosion rates, and $9 \%$ (87) experienced little change (less than $\pm 30 \mathrm{~cm})$ (Fig. 3b).

\section{Comparison to Previous Quantitative Change Analyses}

Reimnitz et al. (1985) divided this stretch of coastline into six sectors based upon morphologic and geologic similarities in order to compare rates of erosion with nautical charts created in 1949 and 1980. Their analysis revealed that, excluding sector 4 (excluded from the analysis since it encompasses all of Pogik Bay), rates of erosion for this stretch of coastline averaged $5.4 \mathrm{~m} \mathrm{a}^{-1}$ but varied considerably between sectors. Erosion rates were highest in sectors 1,3 , and 5, and lowest in sectors 2 and 6 (Table 3).

The results from this study were compared to those of Reimnitz et al. (1985) for roughly the same time interval, and also for the 23-year period 1979-2002. This comparison 
TABLE 3. Comparison of mean annual erosion rates in $\mathrm{m} \mathrm{a}^{-1}$ from this study with those measured by Reimnitz et al. (1985) along five sectors (Fig. 1).

\begin{tabular}{lccc}
\hline \hline Sector & $\begin{array}{c}\text { Reimnitz } \\
(1949-80)\end{array}$ & $\begin{array}{c}\text { This Study } \\
(1955-79)\end{array}$ & $\begin{array}{c}\text { This Study } \\
(1979-2002)\end{array}$ \\
\hline 1 & 8.3 & 6.8 & 8.5 \\
2 & 1.3 & 1.7 & 4.7 \\
3 & 7.8 & 8.3 & 9.6 \\
5 & 7.4 & 7.8 & 9.2 \\
6 & 2.4 & 1.8 & 1.8 \\
Mean & 5.4 & 5.3 & 6.8 \\
\hline \hline
\end{tabular}

suggests that overall rates of erosion agree quite well even though the data sources and temporal coverage differ (Table 3). Thus, the Reimnitz et al. (1985) study serves as a check on the erosion rates measured in this study and suggests that the sectors used in that study could be analyzed further for factors that could explain the differences in erosion rates across the TLSA coastline.

More recently, Mars and Houseknecht (2007) reported erosion between 1955 and 2005 for this stretch of coastline as land area lost, an areal unit, on the basis of cartographic data and Landsat satellite imagery. They found that land area lost per year had more than doubled over that 50-year period, from $0.48 \mathrm{~km}^{2} \mathrm{a}^{-1}$ (1955 to 1985) to $1.08 \mathrm{~km}^{2} \mathrm{a}^{-1}$ (1985 to 2005). If the present study were to report in terms of the same areal unit, land area lost would have increased from $0.49 \mathrm{~km}^{2} \mathrm{a}^{-1}$ (1955 to 1979) to $0.65 \mathrm{~km}^{2} \mathrm{a}^{-1}$ (1979 to 2002): only a $32 \%$ increase, compared to the more than $100 \%$ increase reported by Mars and Houseknecht (2007). This suggests that erosion must have accelerated dramatically between 2002 and 2005, or that the difference results from the coarseness of the Landsat satellite imagery used in the Mars and Houseknecht (2007) study relative to the higher-resolution imagery used in this study.

\section{Loss of Coastal Features}

The Dease and Simpson expedition of 1837 provided the first map (1843) for this segment of the TLSA coast (Fig. 2). Comparison of this map to the map created by Commander Maguire (1852-54) reveals some notable similarities (Simpson, 1843; Maguire, 1854). Of note are the east-west shoreline orientation from Point Drew to Cape Halkett and the absence of Pogik Bay. Leffingwell (1919) also noted these similarities and compared his observations with the maps of Dease and Simpson and Maguire, and suggested that rates of erosion near Point Drew could have averaged $30 \mathrm{~m} \mathrm{a}^{-1}$ from the 1830 s to the early 1900s. More recently, erosion rates near Point Drew have averaged $7.3 \mathrm{~m} \mathrm{a}^{-1}$ (1955-79) and $3.7 \mathrm{~m} \mathrm{a}^{-1}$ (19792002). This suggests that erosion during the latter part of the 19th century could have been much more active near Point Drew than what has occurred during the latter half of the 20th century. Also, comparison of two maps from the mid-1800s with Leffingwell's map (1919) indicates that
Pogik Bay could have formed between 1854 and 1919 through the tapping of a large thaw lake. The mechanism of thaw-lake tapping by coastal erosion and subsequent formation of a bay has recently been described by Mars and Houseknecht (2007).

Another critical observation from the Dease and Simpson voyage was the presence of a small tundra island offshore of present-day Cape Halkett. Dease and Simpson (Simpson, 1843:133) described it as "a small island, separated from the mainland by a channel too shallow for boats. This island appeared to be a favourite resort of the natives in the spring, for we found a spot where baidars [skin-covered boats] had been built, and picked up an antler cut asunder with a saw...this remarkable point was named Cape Halkett." Leffingwell observed that by the early 1900s, the island had become connected to the mainland by a spit, and Reimnitz et al. (1985) reported that the island had disappeared completely by around 1945 .

Historically, the Cape Halkett area has been reported as having the highest mean annual erosion rate $\left(16.7 \mathrm{~m} \mathrm{a}^{-1}\right)$ along the Beaufort Sea coast (Reimnitz et al., 1985). However, our results indicate (1) that this area did not yield the highest mean annual erosion rate over our study period, and (2) that erosion rates actually decreased near Cape Halkett from 1955 to 2002, with average rates of $15.4 \mathrm{~m} \mathrm{a}^{-1}$ during the earlier period (1955-79) and $9.3 \mathrm{~m} \mathrm{a}^{-1}$ during the latter period (1979-2002). The decrease in erosion intensity near Cape Halkett may be explained by the removal of the unvegetated, drained thaw lake basin material that composed the shoreline in the earlier time period. Now, the bluff material consists of vegetated, polygonal tundra, which is likely more resistant to erosion than the unvegetated drained thaw lake basin material because of its higher ice content and the presence of a vegetative mat. This type of information could explain some of the observed spatial variation in shoreline erosion rates.

Leffingwell (1919) also noted several other previously named coastal features that could no longer be distinguished or identified. Point Comfort was mapped by Dease and Simpson (Simpson, 1843) near the mouth of Garry Creek; during Leffingwell's (1919:89) survey he "saw no point at which Point Comfort could be definitely located." The same was true at Point Ellice; Leffingwell (1919:89) noted that Point Ellice was "now a high bank rather than a point of land," as was the case for Point McLeod and Point McPherson, which were high, unbroken banks by the early 1900s. Dease and Simpson (Simpson, 1843) also described a number of reefs to the west of Point Ellice that by 1914 could not be located.

\section{Loss of Cultural/Historical Sites}

Esook Trading Post: The Esook trading post was mapped by the U.S. Coast and Geodetic Survey (USC\&GS) in 1951 and likely dates to the early 1900s (Orth, 1967). Kovacs (1983) noted the presence of five structures in a 

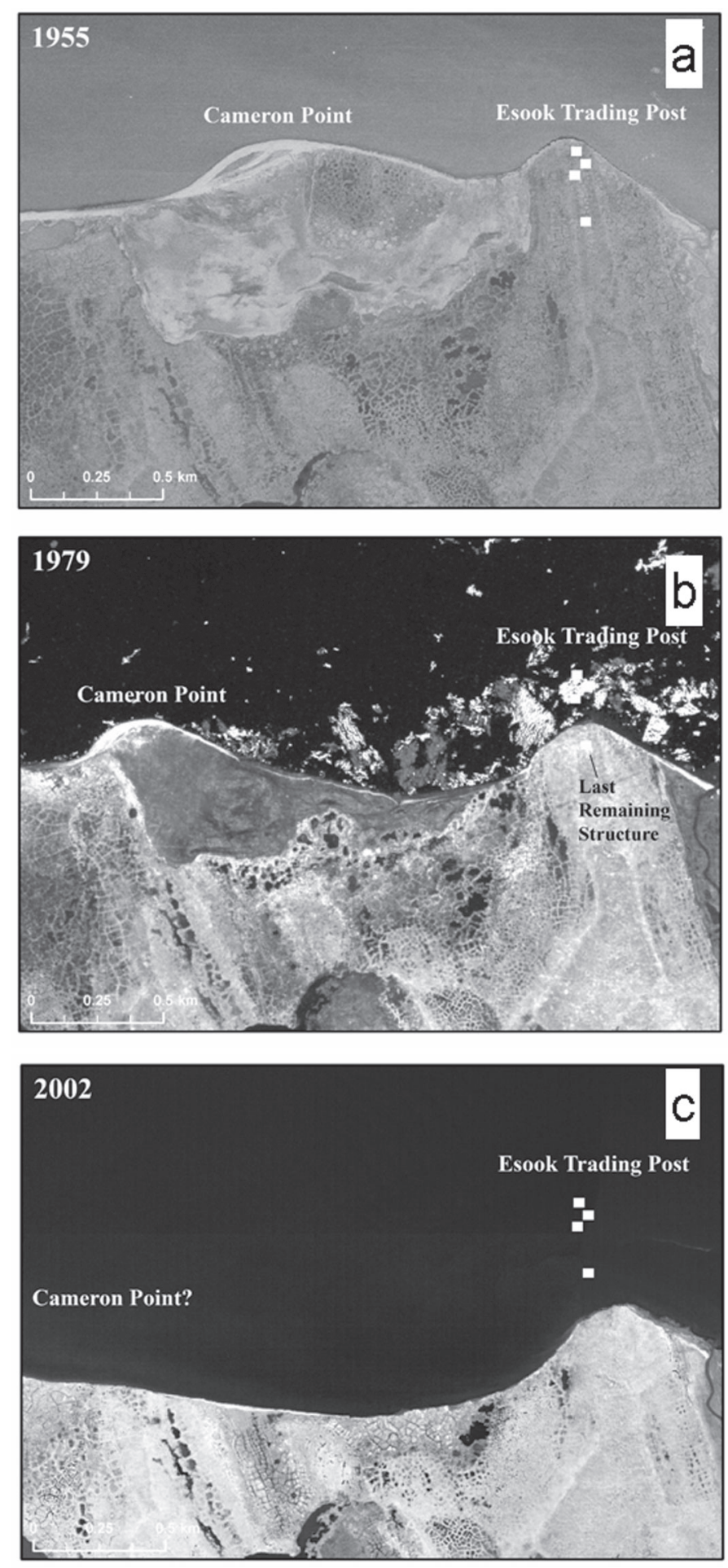
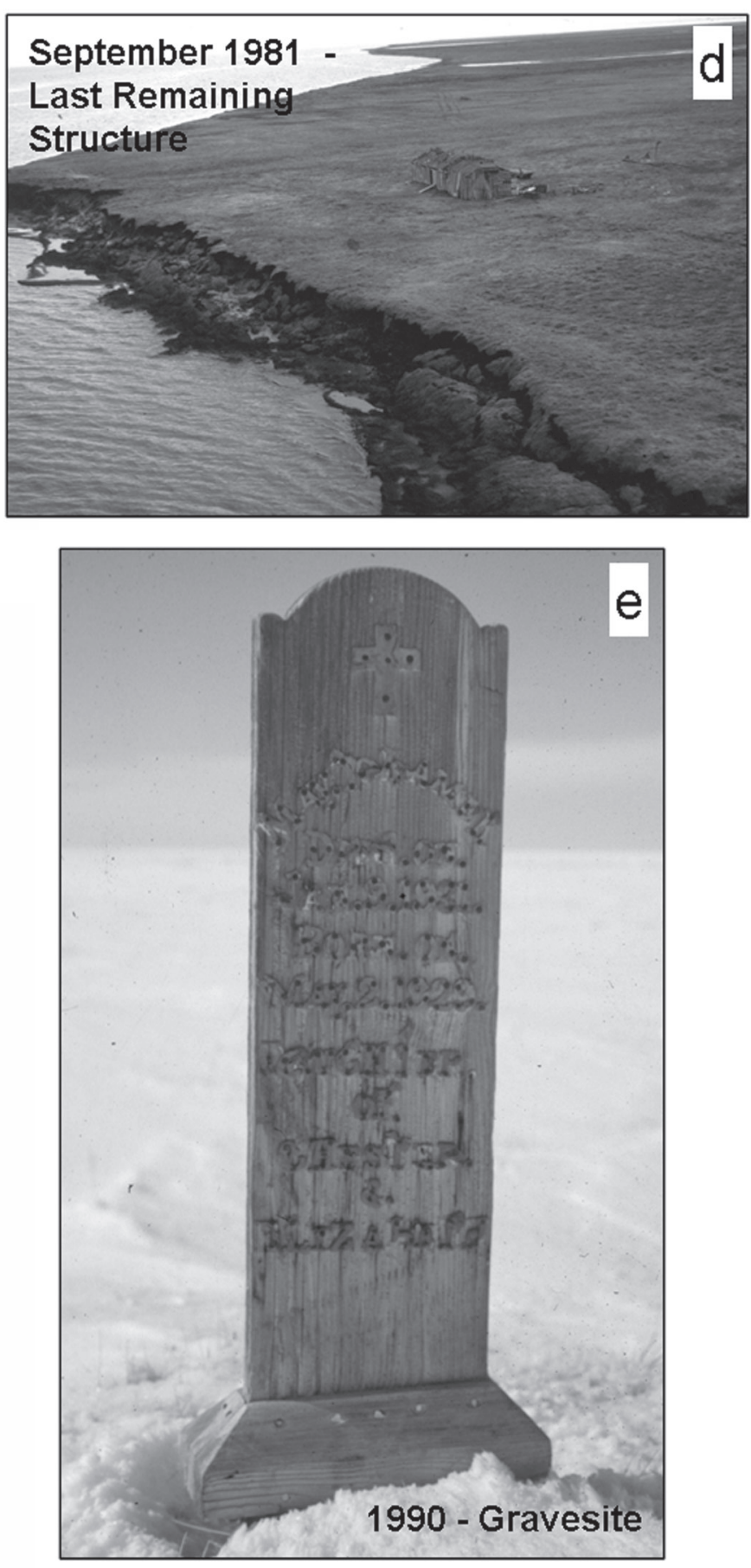

FIG. 4. Photographic time series for the Esook Trading Post site and Cameron Point (a-c), as well as oblique photo of last remaining structure (d) taken in September 1981 (image courtesy of A. Kovacs) and a photo of a gravesite (e) near Esook taken in 1990 (image courtesy of A. Kovacs); the gravesite marker reads "May Jokamer (?), Died on Jan 9 1931, Born on May 2 1929, Daughter of Chester \& Elizabeth." Between 1955 and 1979, all structures were lost except one, and Cameron Point migrated $\sim 0.5 \mathrm{~km}$ to the west. Between 1979 and 2002, the last remaining structure was removed, as well as Cameron Point. During an aerial visit to the site in 2007, it was not possible to locate any graves.

1949 aerial photograph, as well as other features, during his fieldwork conducted in the 1980s. Kovacs (1984) reported that between 1949 and 1981, $410 \mathrm{~m}$ of erosion had occurred at the Esook trading post site and that by 1981, only one structure remained and was located approximately
$19 \mathrm{~m}$ from the coast. This same structure was also visible in the 1979 aerial photography used in our study, and was measured to be $70 \mathrm{~m}$ from the coast at its closest point (Fig. 4). Therefore, between July 1979 and late September $1981,51 \mathrm{~m}$ of erosion occurred, or $25.5 \mathrm{~m} \mathrm{a}^{-1}$, more than 


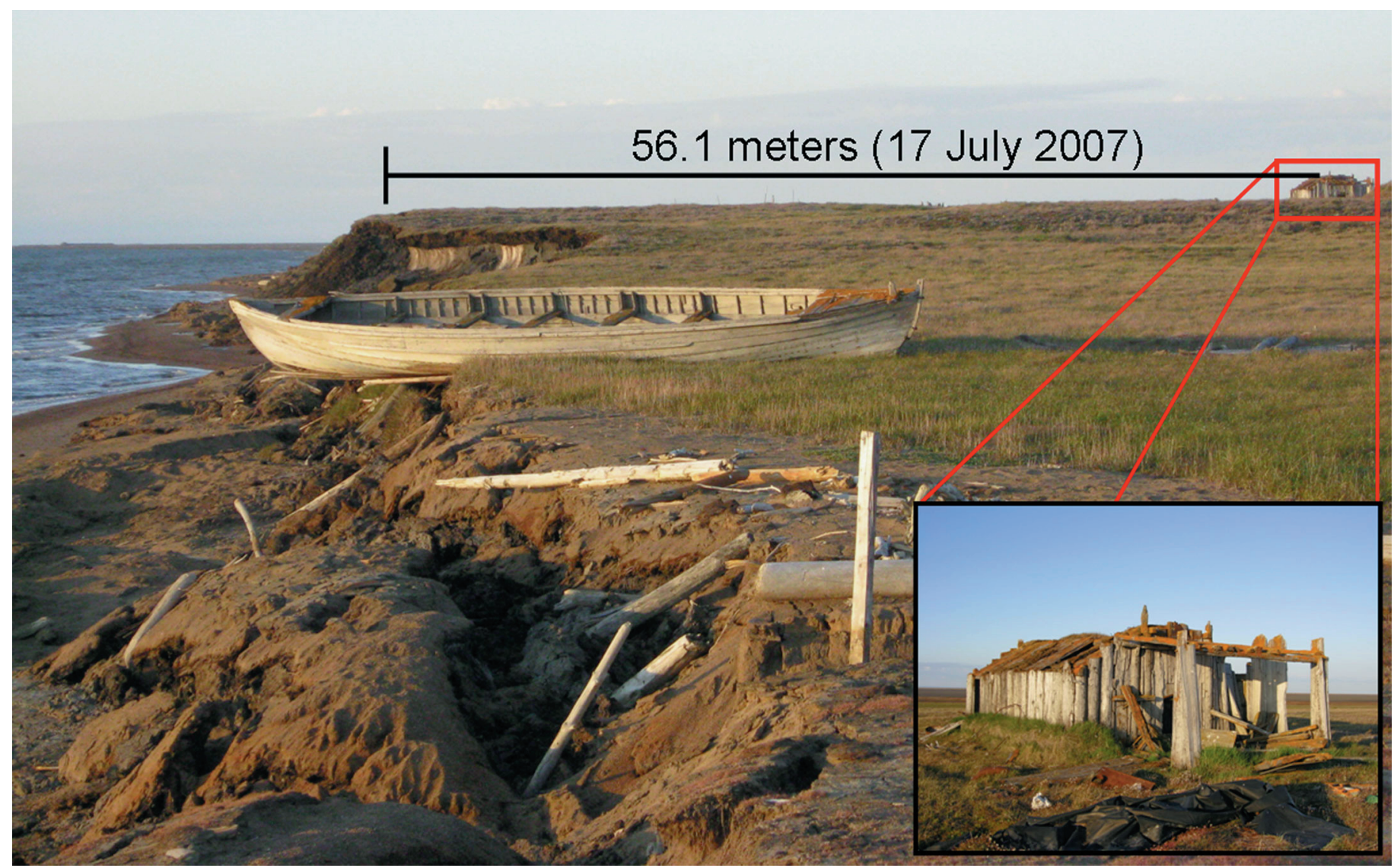

FIG. 5. Ground photographs taken on 17 July 2007 at Kolovik (Qalluvik), showing the last remaining building and an abandoned whaling boat.

double the rate of erosion over the previous $\sim 25$ years $\left(\sim 10 \mathrm{~m} \mathrm{a}^{-1}\right)$. Kowalik (1984) documented two storm events as occurring in the Beaufort Sea during this time period, which could potentially account for the dramatic coastal retreat between 1979 and late 1981. Kovacs measured the distance between the structure and the coast again in the spring of 1982 (19 m), May 1983 (14 m), and May 1984 $(12 \mathrm{~m})$. It would therefore appear that erosion drastically declined following the loss of $51 \mathrm{~m}$ between 1979 and 1981. Further analysis of erosion rates for this area between 1984 and 2002 reveals that rates averaged $8.8 \mathrm{~m} \mathrm{a}^{-1}$. It is likely that the last remaining structure was eroded away shortly after Kovacs's observation in 1984, and the graves and other cultural/historical features were lost to erosion more recently (Fig. 4). This site provides a prime example of the variability in the annual erosion rate and suggests that more frequent observations of coastline positions are warranted in order to monitor and document the loss of historical and cultural sites.

Kokruagarok (Kuugruagaabruk): Kokruagarok (Kuugruagaabruk) was a hunting and fishing site where a number of structures were identified by the USC\&GS in 1951 (Orth, 1967). The site is visible in the 1955 and 1979 aerial photography, and during the period between those dates, erosion rates averaged $3.2 \mathrm{~m} \mathrm{a}^{-1}$. However, during the period 1979-2002, this site was lost, and erosion rates increased to $5.1 \mathrm{~m} \mathrm{a}^{-1}$.
Kolovik (Qalluvik): Kolovik (Qalluvik) was mapped as an abandoned site on the U.S. Geological Survey topographic maps created in 1955. Orth (1967) noted that the settlement was reported as an abandoned village in 1951, and that the name meant "tipping place (where boats are emptied of water)." Erosion rates at this site were modest over the study period. However, rates increased from $0.2 \mathrm{~m} \mathrm{a}^{-1}$ during 1955-79 to $1.6 \mathrm{~m} \mathrm{a}^{-1}$ during 1979-2002.

When we visited this site on 17 July 2007, we found one structure still standing, as well as remnants of other structures, ice cellars, gravesites, and two whaling boats. Measuring the distance from the standing structure and whaling boats to the bluff edge, we found $56.1 \mathrm{~m}$ of land remaining between the southern corner post of the structure and the bluff edge. One of the whaling boats was $13.2 \mathrm{~m}$ from the bluff edge, but one-third of the second boat was already overhanging the bluff (Fig. 5). Thus, Kolovik provides an example of a site that is currently threatened by coastal erosion. Steps should be taken to prevent losing a potentially significant cultural and historical site.

Deer Pound: Dease and Simpson (Simpson, 1843:135 136) named and described this area as they witnessed it in 1837:

On examining the vicinity, we discovered a large reindeer pound, simply contrived with double rows of turf set up to represent men, and inclosing a space of ground lower than 
the rest. The inclosure was two miles broad at the beach, and narrowed towards a lake of some extent, where the unsuspecting animals are surrounded and speared in the water... The point of our encampment was about twenty feet high; and across the deer pound, at the distance of four miles, the land formed another point of equal elevation.

Leffingwell (1919) observed this same area around 70 years later and found that Point McLeod and Point McPherson had been eroded to such a degree that they were no longer distinguishable promontories, and that the lake mentioned by Dease and Simpson was now about $3.2 \mathrm{~km}$ inland. Analysis of the 1955 imagery shows that this lake had recently been tapped by the eroding coastline, which suggests that between the early 1900s and 1955, an extreme amount of erosion had occurred. This erosion could be related to the removal of the tundra mat for the construction of the deer pound that existed here in the 1800 s, or an inaccurate measurement by Leffingwell (1919) could have affected the estimate.

Erosion rates at this site from 1955 to 2002 were among the highest measured along this stretch of coastline during the latter half of the 20th century. Over the entire period, the average rate was $13.8 \mathrm{~m} \mathrm{a}^{-1}\left(\min =8.9 \mathrm{~m} \mathrm{a}^{-1} ; \max =18.3 \mathrm{~m} \mathrm{a}^{-1}\right)$, with an increase from $11.5 \mathrm{~m} \mathrm{a}^{-1}\left(\min =6.5 \mathrm{~m} \mathrm{a}^{-1} ; \max =\right.$ $\left.15.2 \mathrm{~m} \mathrm{a}^{-1}\right)$ during $1955-79$ to $16.2 \mathrm{~m} \mathrm{a}^{-1}\left(\min =10.6 \mathrm{~m} \mathrm{a}^{-1}\right.$; $\max =24.3 \mathrm{~m} \mathrm{a}^{-1}$ ) during $1979-2002$. Of note is that the highest erosion rates along this stretch of coastline occurred in an unvegetated, drained thaw lake basin.

\section{Loss of Modern Sites/Infrastructure}

Lonely DEW Station: The Lonely DEW station, constructed in 1955, was one of 58 sites strategically placed throughout North America as part of an air defense program carried out during the Cold War. The Lonely DEW station was constructed on the landward side of a lagoon and consists of a landing strip, small road network, radar dome, antennae, hangars, and various other buildings. In 1955, the shoreward side of the landing strip was located approximately $700 \mathrm{~m}$ from the coast; by 1979 , however, the shoreward side had expanded and roughly $6 \mathrm{~m}$ of erosion had occurred along the coast, leaving only about $650 \mathrm{~m}$ of land. From 1979 to 2002, coastal erosion increased at this site, and the shoreline migrated inland by $46 \mathrm{~m}$, leaving about $600 \mathrm{~m}$ between the shoreward side of the landing strip and the coast. Thus, it appears that the Lonely DEW line station was well positioned during construction and that it is not in imminent danger from the transgressing sea.

Petroleum Test Wells: Three petroleum test wells were drilled in the northern TLSA area by Husky Oil NPR Operation, Inc. during the 1970s: the Foran test well (1977), the Point Drew test well (1978), and the J.W. Dalton test well (1978-79). In each case, the decision was made to plug and abandon the borehole because of the low potential for petroleum recovery, but the gravel pads, pilings, and wellheads remain.
The Foran test well is located farthest inland. During the late $1970 \mathrm{~s}$, the site was approximately $960 \mathrm{~m}$ from the coast at its closest point. By 2002, the coastline had migrated inland $280 \mathrm{~m}$, leaving $680 \mathrm{~m}$ between the edge of the gravel pad and the shore. At the average 1979 to 2002 erosion rate, it will therefore take another 55 years for the coast to reach the Foran test well site. The Point Drew site was located $\sim 290 \mathrm{~m}$ from the coast when it was constructed in 1979. By 2002 , only $90 \mathrm{~m}$ of land remained between the edge of the gravel pad and the shore, indicating that $\sim 200 \mathrm{~m}$ of erosion had occurred over the 23-year period. If this average rate of erosion is sustained over the coming years, the coastline will abut the edge of the gravel pad by 2012. When constructed, the gravel pad at the J.W. Dalton test well site was located $230 \mathrm{~m}$ from the coast. During the next 23 years, nearly $260 \mathrm{~m}$ of land was eroded. Thus, the infrastructure at this site was already being eroded by 2002, and by 2004 the majority of the site had been consumed. This type of analysis is critical for land and resource managers as the coastline migrates closer to modern infrastructure.

\section{CONCLUSIONS}

This study used high-resolution vertical aerial photography (1:40000 to $1: 60000 ; 2.5 \mathrm{~m}$ pixel resolution) from 1955, 1979, and 2002 to determine mean annual erosion rates along a $\sim 100 \mathrm{~km}$ stretch of the Beaufort Sea coast at $100 \mathrm{~m}$ intervals for each time period and found that:

- Mean annual erosion rate for the $100 \mathrm{~km}$ stretch of coastline was $5.6 \mathrm{~m} \mathrm{a}^{-1}$ between 1955 and 2002; however, this rate increased from $5.0 \mathrm{~m} \mathrm{a}^{-1}$ during 1955-79 to $6.2 \mathrm{~m} \mathrm{a}^{-1}$ during 1979-2002 (an increase of 24\%).

- From the first time period (1955-79) to the second (1979-2002), the mean rate of erosion increased at $60 \%$ (598), decreased at 31\% (307), and changed less than $\pm 30 \mathrm{~cm}$ at $9 \%$ (87) of the 992 points analyzed in both time periods.

- Combining our modern photographic analysis with historical observations revealed that coastal erosion has been a major landscape-altering mechanism over at least the historical record. Of the seven coastal features identified in the 1830 s, only two remain. Also, of the four known cultural/historical sites along this coastline, only one remains. This last remaining site is being threatened by shoreline erosion, and steps should be taken to preserve the site if it is deemed important.

- Loss of modern infrastructure has also occurred since 1950. Of the three petroleum test wells drilled near the coast, one has been destroyed, erosion of the second is expected within the next decade, and the third will be consumed within the next 50 years if the mean 19792002 erosion rate is maintained. The Lonely DEW station appears to have been built in a protected location and is not immediately threatened by coastal erosion. 


\section{ACKNOWLEDGEMENTS}

This work was supported by the U.S. Geological Survey, Alaska Science Center. Use of trade, product, or firm names does not imply endorsement by the United States government. This paper benefited from the reviews of A.C. Brown, Ann Gibbs, Carl Markon, Dave Yokel, Shane Walker, Julie Brigham-Grette, and one anonymous reviewer.

\section{REFERENCES}

ALASKA OCEAN OBSERVING SYSTEM. 2008. Prudhoe Bay tide gauge data 2002. http://ak.aoos.org/op/data.php?region $=$ AK\&name $=$ surface_tide.

BARNES, P.W., REIMNITZ, E., and ROLLYSON, B.P. 1992. Map showing Beaufort Sea coastal erosion and accretion between Flaxman Island, northeastern Alaska, and the Canadian border (1:82,000). U.S. Geological Survey, Miscellaneous Investigations, Series Map I-1182-H. 22 p.

BIRD, ECF. 2000. Coastal geomorphology: An introduction. New York: Wiley. 322 p.

BIRD, K.J., and HOUSEKNECHT, D.W. 2002. U.S. Geological Survey 2002 petroleum resource assessment of the National Petroleum Reserve in Alaska (NPRA). Fact Sheet 045-02. Reston, Virginia: U.S. Geological Survey. 1 p., http://pubs.usgs. gov/fs/2002/fs045-02/.

BOLLINGER, K.S., and DERKSEN, D.V. 1996. Demographic characteristics of molting black brant near Teshekpuk Lake, Alaska. Journal of Field Ornithology 67:141-158.

BRIGHAM-GRETTE, J. 2001. New perspectives on Beringian Quaternary paleogeography, stratigraphy, and glacial history. Quaternary Science Review 20:15-24.

BRIGHAM-GRETTE, J., and CARTER, L.D. 1992. Pliocene marine transgressions of northern Alaska: Circumarctic correlations and paleoclimatic interpretations. Arctic 45(1):74-89.

BRIGHAM-GRETTE, J., and HOPKINS, D.M. 1995. Emergent marine record and paleoclimate of the last interglaciation along the northwest Alaskan coast. Quaternary Research 43(2): $159-173$.

BROWN, J., FERRIANS, O.J., Jr., HEGINBOTTOM, J.A., and MELNIKOV, E.S. 1997. Circum-Arctic map of permafrost and ground-ice conditions. U.S. Geological Survey Circum-Pacific Map Series CP-45, 1:100,000.

BROWN, J., JORGENSON, M.T., SMITH, O.P., and LEE, W. 2003. Long-term rates of erosion and carbon input, Elson Lagoon, Barrow, Alaska. In: Phillips, M., Springman, S.M., and Arenson, L.U., eds. ICOP 2003 Permafrost: Proceedings of the 8th International Conference on Permafrost. Rotterdam, Netherlands: AA Balkema Publishers. 101-106.

CARSON, C.E., and HUSSEY, K.M. 1962. The oriented lakes of Arctic Alaska. Journal of Geology 70:417-439.

CARTER, L.D., BROUWERS, E.M., and MARINCOVICH, L., Jr. 1988. Nearshore marine environments of the Alaskan Beaufort Sea during deposition of the Flaxman Member of the Gubik Formation. In: Galloway, J.P., and Hamilton, T.D., eds. Geologic studies in Alaska by the U.S. Geological Survey during 1987. U.S. Geological Survey Circular 1016:27-30.

DINTER, D.A., CARTER L.D., and BRIGHAM-GRETTE, J. 1990. Late Cenozoic geologic evolution of the Alaskan North Slope and adjacent continental shelves. In: Grantz, A., Johnson, L., and Sweeney, J.F., eds. The geology of North America, Vol. 1: The Arctic Ocean region. Boulder, Colorado: The Geological Society of America. 459-490.

EISNER, W.R., BOCKHEIM, J.G., HINKEL, K.M., BROWN, T.A., NELSON, F.E., PETERSON, K.M., and JONES, B.M. 2005. Paleoenvironmental analyses of an organic deposit from an erosional landscape remnant, Arctic Coastal Plain of Alaska. Palaeogeography, Palaeoclimatology, Palaeoecology 217: 187-204.

HARPER, J.R. 1990. Morphology of the Canadian Beaufort Sea coast. Marine Geology 91:75-91.

HINKEL, K.M., EISNER, W.R., BOCKHEIM, J.G., NELSON, F.E., PETERSON, K.M., and DAI, X. 2003. Spatial extent, age, and carbon stocks in drained thaw lake basins on the Barrow Peninsula, Alaska. Arctic, Antarctic and Alpine Research 35: 291-300.

HINKEL, K.M., FROHN, R.C., NELSON, F.E., EISNER, W.R., and BECK, R.A. 2005. Morphometric and spatial analysis of thaw lakes and drained thaw lake basins in the Western Arctic coastal plain, Alaska. Permafrost and Periglacial Processes 16:327-341.

HOPKINS, D.M. 1967. Quaternary marine transgressions in Alaska. In: Hopkins, D.M., ed. The Bering Land Bridge. Stanford: Stanford University Press. 47-90.

1973. Sea level history in Beringia during the past 250,000 years. Quaternary Research 3:520-540.

JORGENSON, M.T., and BROWN, J. 2005. Classification of the Alaskan Beaufort Sea coast and estimation of carbon and sediment inputs from coastal erosion. Geo-Marine Letters 25:69-80.

JORGENSON, M.T., MACANDER, M., JORGENSON, J.C., PING, C.L., and HARDEN, J. 2003. Ground ice and carbon characteristics of eroding coastal permafrost at Beaufort Lagoon, northern Alaska. In: Phillips, M., Springman, S.M., and Arenson, L.U., eds. ICOP 2003 Permafrost: Proceedings of the 8th International Conference on Permafrost. Rotterdam, Netherlands: AA Balkema Publishers. 495-500.

KOVACS, A. 1983. Shore ice ride-up and pile-up features, Part I: Alaska's Beaufort Sea coast. CRREL Report 83-9. Hanover, New Hampshire: Cold Regions Research and Engineering Laboratory, U.S. Army Corps of Engineers. 59 p.

1984. Shore ice ride-up and pile-up features, Part II: Alaska's Beaufort Sea coast - 1983 and 1984. CRREL Report 84-26. Hanover, New Hampshire: Cold Regions Research and Engineering Laboratory, U.S. Army Corps of Engineers. 33 p.

KOWALIK, Z. 1984. Storm surges in the Beaufort and Chukchi seas. Journal of Geophysical Research 89:10570-10578.

LEFFINGWELL, E.K. 1919. The Canning River region, northern Alaska. U.S. Geological Survey Professional Paper 109. 251 p.

LEWELLEN, R.I. 1970. Permafrost erosion along the Beaufort Sea coast. Denver: Geography and Geology Department, University of Denver. $25 \mathrm{p}$. 
MACKAY, J.R. 1986. Fifty years (1935 to 1985) of coastal retreat west of Tuktoyaktuk, District of Mackenzie. Current Research Part A, Geological Survey of Canada Paper 86-1A:727-735.

MAGUIRE, R.N. 1854. Narrative of the year 1852-53. British Blue Books 42:160-186.

MANLEY, W.F. 2004. Spatial analysis of coastal erosion over five decades near Barrow, Alaska. (Abstract only). 34th Arctic Workshop, 11-13 March 2004, Boulder, Colorado.

MARS, J.C., and HOUSEKNECHT, D.W. 2007. Quantitative remote sensing study indicates doubling of coastal erosion rate in the past $50 \mathrm{yr}$ along a segment of the Arctic coast of Alaska. Geology 35(7):583-586.

ORTH, D.J. 1967. Dictionary of Alaska place names. U.S. Geological Survey Professional Paper 567. 1084 p.

PERSON, B.T., PRICHARD, A.K., CARROLL, G.M., YOKEL, D.A., SUYDAM, R.S., and GEORGE, J.C. 2007. Distribution and movements of the Teshekpuk caribou herd, 1990-2005: Prior to oil and gas development. Arctic 60(3):238-250.

PÉWÉ, T.L. 1975. Quaternary geology of Alaska. U.S. Geological Survey Professional Paper 835. 145 p.

REIMNITZ, E., and MAURER, D.K. 1979. Effects of storm surges on the Beaufort Sea coast, northern Alaska. Arctic 32(4): $329-344$.
REIMNITZ, E., GRAVES, S.M., and BARNES, P.W. 1985. Beaufort Sea coastal erosion, shoreline evolution, and sediment flux. U.S. Geological Survey Open-File Report 85-380. 67 p.

SELLMANN, P.V., BROWN, J., LEWELLEN, R.I., McKIM, H., and MERRY, C. 1975. The classification and geomorphic implications of thaw lakes on the Arctic coastal plain, Alaska. CRREL Research Report 344. Hanover, New Hampshire: Cold Regions Research and Engineering Laboratory, U.S. Army Corps of Engineers. 21 p.

SIMPSON, T. 1843. Narrative of the discoveries on the north coast of America, effected by the officers of the Hudson's Bay Company during the years 1836-1839. London: Richard Bentley. $419 \mathrm{p}$.

SOLOMON, S.M. 2005. Spatial and temporal variability of shoreline change in the Beaufort-Mackenzie region, Northwest Territories, Canada. Geo-Marine Letters 25:127-137.

THIELER, E.R., HIMMELSTOSS, E.A., ZICHICHI, J.L., and MILLER, T.L. 2005. Digital Shoreline Analysis System(DSAS) version 3.0: An ArcGIS extension for calculating shoreline change. U.S. Geological Survey Open-File Report 2005-1304. 